\title{
Determinants of Corporate Compliance with Modern Slavery Reporting
}

\author{
Abstract \\ Purpose: This paper investigates the determinants of corporate compliance with the Transparency in \\ Supply Chains provision of the UK Modern Slavery Act. While recent scholarship has described what \\ firms are doing to comply with this Act, no attempt has been made to explain their behaviour.
}

Design: A predictive model of corporate compliance with modern slavery reporting is tested using secondary data from FTSE 350 firms. The model is informed by institutional theory and, in particular, by Oliver's (1991) insights into the conditions under which firms respond to institutional pressures.

Findings: Compliance with modern slavery reporting is found to be significantly related to firm size, prior social responsibility commitment, network involvement, industry and headquarter base (UK versus non-UK). Other predictors like media exposure, shareholder concentration and profitability are found to be non-significant.

Research limitations: The focus is on the 350 largest publicly-listed companies in the UK. The stances that firms outside of this cohort are taking on modern slavery reporting still need to be investigated.

Practical implications: Compliance with the UK Modern Slavery Act varies by industry. Regulators should consider this as part of risk profiling strategies and follow-up inspection of firms.

Originality: This paper provides the first theoretically-grounded examination of the organisational and environmental factors that determine corporate compliance with modern slavery reporting.

Keywords modern slavery, supply chains, corporate compliance, institutional theory, secondary data.

Paper type Research paper

\section{Introduction}

Firms are under pressure to do more to combat modern slavery risks in their supply chains. This is the culmination not only of campaigning and advocacy by non-government organisations (NGOs) like Antislavery International, The Ethical Trade Initiative and Stronger Together, but also the result of direct government intervention. The latter is exemplified through the UK Modern Slavery Act. It contains a Transparency in Supply Chains provision, which obliges large firms to publish an annual modern slavery statement setting out the steps that they have taken to de-risk their supply chain from modern slavery (HM Government, 2015). Research recently published in Supply Chain Management: An International Journal (23/2) by Stevenson and Cole (2018) described the type of information textile firms have included in their statements and what this implies about their preparedness for managing modern slavery risks. We extend this emergent line of inquiry by switching the focus from descriptive to predictive analysis. Specifically, we examine the conditions under which firms are likely to conform to institutional expectations on modern slavery reporting.

Modern slavery is "the status or condition of a person over whom any or all of the powers attaching to the right of ownership are exercised" (Office of the High Commissioner for Human Rights, Undated). In practice, this means one party forcing another party to work, controlling them through threats, restricting their movement, treating them as a commodity and financially exploiting them (Antislavery International, Undated; Crane, 2013, p. 51). By any reckoning, modern slavery has received scant attention in supply chain management (SCM) research (Gold et al., 2015). Apart from the previously cited study by Stevenson and Cole (2018) and earlier work by Winstanley et al. (2002), Crane (2013), New (2015) and Crane et al. (2017), there has been a distinct lack of academic engagement with modern slavery in supply chains. Systematic literature reviews indicate that this is part of a tendency 
in SCM research to privilege the environmental dimension of sustainability over the social dimension (Carter and Easton, 2011; Touboulic and Walker, 2015; Zorzini et al., 2015). Even SCM research focused on social sustainability has sidestepped modern slavery (Nakamba et al., 2017).

There is reason to believe, however, that modern slavery will assume greater prominence in SCM research. Media coverage of forced labour incidents in the domestic supply chains of high-street retailers like Next and John Lewis has heightened public awareness of the problem (www.bbc.co.uk, 2016). What is more, the evidence suggests that modern slavery is becoming more prevalent domestically and internationally. In England and Wales there was a year-on-year increase of $159 \%$ in modern slavery offences recorded for 2016-2017 and the number of persons affected is in the region of 13,000 (HM Government, 2017). This pattern is mirrored internationally, with the total number of modern slavery victims almost doubling from 20.9 million in 2011 (ILO, 2012) to 40.3 million in 2016 (ILO, 2017). Against this backdrop, there are growing institutional pressures - regulatory, normative and cultural-cognitive - on firms to be transparent over the modern slavery risks they face and their strategies for mitigating these risks. Inevitably, this means richer and more accessible data for researchers to work with.

The particular focus of this paper is on the determinants of corporate compliance with modern slavery reporting. With the exception of Birkey et al. (2018), there has been no attempt to test these determinants. Understanding of the causes of compliance or non-compliance with modern slavery reporting is limited as a result. To move the debate forward we specify and test a predictive model of compliance with modern slavery reporting. Our model is adapted from Oliver (1991) and her insights into the determinants of compliance with institutional standards, of which modern slavery reporting is an example. We test the model among FTSE 350 firms using data from a range of secondary sources and databases. The paper makes its empirical contribution by providing the most comprehensive answer yet to the question of why compliance with modern slavery reporting varies across firms. It makes its theoretical contribution by applying Oliver's (1991) framework for the first time in a sustainable SCM context. We operationalise this framework in the case of modern slavery reporting, but its utility is likely to extend to other aspects of sustainable SCM.

Before proceeding, we wish to stress that modern slavery reporting is about more than buyer-supplier dyads. This is evident in the terminology used throughout the UK Modern Slavery Act, which refers to supply chains rather than suppliers (HM Government, 2015). It is equally evident in the content of modern slavery reports, many of which discuss actions taken with sub-suppliers as well as lead suppliers (Stevenson and Cole, 2018). Some financial institutions and travel providers even include customers and service users in modern slavery risks assessments (see, for example, Barclays, 2016), which tells us that modern slavery reporting is an end-to-end supply chain issue. The remainder of the paper is structured as follows. Section two presents a predictive model of corporate compliance with modern slavery reporting. Section three explains the methodology, including operationalisation and measurement of predictor and outcome variables. All data comes from secondary sources. Section four presents the findings from ordinal and binary logistic regression procedures used to test the model. The fifth section discusses the findings using an institutional theory lens. The sixth section sets out practitioner implications before concluding with the research limitations.

\section{Theoretical Framework}

The Transparency in Supply Chains provision of the UK Modern Slavery Act legally requires all large firms operating in the UK to publish an annual statement detailing their actions to prevent modern slavery in their supply chains (HM Government, 2015). Inter alia, firms are expected to include information on their supply chain characteristics, policies, due diligence, risk assessment, risk 
management, performance metrics and training as they relate to modern slavery. The Transparency in Supply Chains provision represents an institutional pressure on firms to combat modern slavery. Institutional theory predicts that firms respond to such institutional pressure by adjusting their policies and practices in accordance with the expectations of institutional stakeholders (Meyer and Rowan, 1977; DiMaggio and Powell, 1983; Scott, 2008). The rationale for doing so is to maintain social legitimacy (Dowling and Pfeffer, 1975). As the same authors explain, "organizations seek to establish congruence between the social values associated with or implied by their activities and the norms of acceptable behaviour in the larger social system" (1975, p. 122). This logic can be used to explain why firms are placing greater emphasis on responsible sourcing practices (Hoejmose et al., 2014a).

Institutional pressures are not deterministic of corporate behaviour in every case and firms may be unable or unwilling to comply. The originators of new institutionalism, Meyer and Rowan (1977), acknowledged that firms sometimes display superficial or "ceremonial" conformity with institutional rules and norms. This led Oliver (1991) to propose a contingent view of institutional pressures and their effects on firms. It suggests that responses to institutional pressures fall into one of five categories: defiance, avoidance, compromise, acquiescence and manipulation. The response type a firm exhibits depends on cause, constituent, content, control and context factors linked to the institutional pressure impacting them. Oliver (1991) explains that cause refers to the rationale for the institutional pressure, constituents are internal or external stakeholders exerting pressure on the firm to be institutionally compliant, content is the set of requirements that the firm is expected to obey, control is the mechanisms through which the institutional pressure is applied and context is the environmental setting in which the pressures play out.

Oliver's framework (1991) provides the theoretical basis for predicting corporate compliance with modern slavery institutional pressures in this study. To operationalise it we draw from research into the determinants of socially responsible behaviour by firms. Campbell (2007), for instance, proposed a number of economic and institutional conditions under which firms are likely to practise socially responsible behaviour. These take in control-related factors like NGO activism and regulatory oversight, constituent-related factors like input from labour and community groups and contextrelated factors like the financial health of the firm. Within the sustainable SCM field, control factors such as industry peer pressure, media attention and consumer campaigning have been identified as driving responsible sourcing (Park-Poaps and Rees, 2010; Deegan and Islam, 2014; Kauppi and Hannibal, 2017). Similar opinions have been offered in respect of "green" SCM practices. For example, Tate et al. (2011) have proposed that industry coalitions and competitor behaviour exercise forms of normative and mimetic control on firms for "green" SCM.

Research on socially responsible reporting by firms provides additional insights into probable determinants of corporate compliance with modern slavery reporting. Findings from these studies point to several organisational factors that account for if and to what extent firms report on corporate social responsibility (CSR) issues. In this vein, support has been forthcoming for organisational characteristics including size, public profile and industry classification as influencing CSR disclosures (Reverte, 2009; Gamerschlag et al., 2011). This suggests that modern slavery as a societal problem could be more germane to larger, more visible firms and firms operating in industries with higher exposure to its risks. There is also some evidence to suggest that constituents like shareholders, company directors and audit committees steer firms' approaches to CSR reporting (Haniffa and Cooke, 2005; Barako et al., 2006; Brammer and Pavelin, 2006), as there is in relation to the profitability and leverage positions of firms (Perez-Batres et al., 2012). Insights from the above literatures provide the basis for operationalising cause, constituent, content, control and context factors as they relate to 
corporate compliance with modern slavery reporting. Hypothesised relationships are depicted in Fig.1 and defended in sections 2.1 through to 2.5 underneath.

Fig. 1 Predictive model of corporate compliance with modern slavery reporting

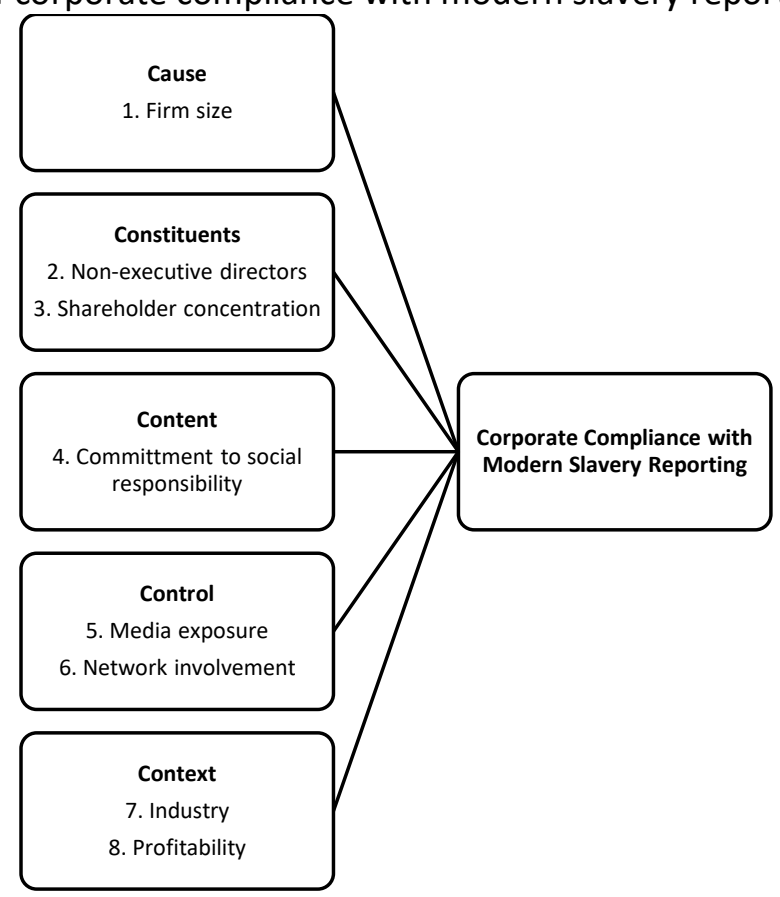

\subsection{Cause}

Modern slavery is one of the main activist issues facing corporations. This can be seen in Anti-slavery International campaigns like Cotton Crimes, which urges retailers not to source cotton from countries where it is alleged that forced labour is used in its cultivation. It can equally be seen in the Church of England's Clewer Initiative, which supports church networks in detecting modern slavery in their towns and cities (Burgess, 2018). The reputational consequences associated with modern slavery risks have risen as a result. Large firms are particularly affected. Whereas small firms operate under the institutional radar, large firms are scrutinised by government, NGOs and the media. This was illustrated in 2018 when the Independent Anti-Slavery Commissioner wrote to the top one hundred publicly-listed UK firms reminding them of their reporting obligations under the Modern Slavery Act (Office of the Independent Anti-slavery Commissioner, 2018). The visibility of large firms means that reluctance by them to signal compliance with prevailing standards on responsible SCM will invite public disapproval and even official censure (Hoejmose et al., 2014a). Consequently, there is more at stake for large firms when it comes to satisfying institutional expectations on modern slavery reporting. This leads to the following hypothesis.

H1: Firm size is positively associated with corporate compliance on modern slavery reporting.

\subsection{Constituents}

Internal and external constituents can push firms to take a proactive stance against modern slavery. Here the focus is on two constituent groups: non-executive board directors and shareholders. The UK Corporate Governance Code recommends that at least half of the company board should consist of non-executive independent directors. This is because non-executive directors bring an outside perspective to organisational planning and oversight (Roberts et al., 2005). They not only monitor managerial decision making, but also provide advice to executive management (ibid). Their external and often independent status means that non-executive directors are better positioned than managers to represent the views of stakeholders on sustainability matters (Haniffa and Cooke, 2005). 
This extends to combating modern slavery, where non-executives can advise on and oversee appropriate policies, practices and procedures. Research suggests that representing stakeholder interests and making corporate governance disclosures is supported by the extent of non-executive representation on the company board (Brammer and Pavelin, 2006), although negative findings have also been returned (Barako et al., 2006). On balance, non-executive representation is conducive to socially responsible behaviour. This leads to the following hypothesis.

H2a: Non-executive representation on the company board is positively associated with corporate compliance on modern slavery reporting.

Agency theory tells us that there are inherent tensions between the interests of owners (i.e. principals) and the actions of managers (i.e. agents) (Eisenhardt, 1989). How firms resolve these agency tensions varies according to their shareholder concentration. Firms with relatively high shareholder concentration prefer direct engagement with major shareholders to ease principal-agent tensions (Brammer and Pavelin, 2006). Smaller numbers of shareholders and a low public ownership interest in the firm makes this strategy feasible. It can be witnessed, for example, when controlling shareholders are permitted to have a representative on the board of directors. Firms with a relatively low shareholder concentration, on the other hand, are reliant on formal reporting to communicate with and maintain the trust of their many and dispersed owners. Moreover, this is something that their shareholders expect. Findings from across a number of countries bear out this inverse relationship between shareholder concentration and social reporting (Barako et al., 2006; Gamerschlag et al., 2011). We anticipate that as shareholder concentration increases, the impetus for firms to publicly report on modern slavery risks decreases. This leads to the following hypothesis.

$\mathrm{H} 2 \mathrm{~b}$ : Shareholder concentration is negatively associated with corporate compliance on modern slavery reporting.

\subsection{Content}

The objectives of the UK Modern Slavery Act will be familiar to some firms. Guidance documentation accompanying the Act acknowledges as much, stating: "an organisation may already be undertaking procedures or have specific policies that go some way to addressing the issue of modern slavery and may already be disclosing this in some form" (HM Government, 2015, p. 9). Studies show that increasing numbers of corporations are doing precisely this by adopting human rights policies and signing up to international accords designed to eradicate forced labour and child labour (Preuss, 2009; Preuss and Brown, 2012). In such cases there is prima facie compatibility between institutional expectations on modern slavery reporting and pre-existing corporate values and commitments. Compatibility of this kind makes acceptance of institutional demands palatable for firms. Incompatibility can cause them to evade or rebuff these same demands in order to protect their core operations (Meyer and Rowan, 1977). Notably, Birkey et al. (2018) found that firms with a history of social responsibility reporting made better quality disclosures under the California Transparency in Supply Chains Act. This leads to the following hypothesis.

H3: Prior social responsibility commitment is positively associated with corporate compliance on modern slavery reporting.

\subsection{Control}

Institutional pressures can take coercive, normative and mimetic forms (DiMaggio and Powell, 1983). As all large firms operating in the UK are obliged to report on modern slavery, coercion in a legal sense is invariant. Normative and mimetic institutional pressures are not invariant. The degree to which firms' experience these pressures may influence their approach to modern slavery reporting. Normative pressures impose a social obligation on firms to behave responsibly (DiMaggio and Powell, 
1983). It was, for example, a sense of social obligation that prompted UK universities to embrace sustainability in their food supply chains (Sayed et al., 2017). While normative pressures originate from many sources, the media is especially germane to socially responsible SCM (Park-Poaps and Rees, 2010) and is known to influence how firms report on it (Reverte, 2009). Media outlets, often after receiving alerts from NGOs, publicise incidents where corporations have been compromised by labour rights abuses (Deegan and Islam, 2014). A recent Sky News investigation linking child labour in Congolese cobalt mines to the supply chains of consumer electronics firms is a case in point (www.skynews.com, 2018). Media exposure of this type makes named firms vigilant about modern slavery risks and, arguably, more transparent about their strategies to manage these risks. This leads to the following hypothesis.

H4a Media exposure is positively associated with corporate compliance on modern slavery reporting.

Mimetic pressure takes effect when firms, uncertain over how to navigate an institutional environment in flux, decide to mimic or copy the behaviour of their peers (DiMaggio and Powell, 1983). Mimetic pressures have an important role to play in the uptake of sustainable SCM practices, as demonstrated by Hoejmose et al. (2014b), Sancha et al. (2015) and Sayed et al. (2017). An important medium through which mimesis takes place is business networks (Tate et al., 2011). It is along networks that "shared understandings" emerge over how the industry should orient itself towards its institutional environment (Scott, 2008). Involvement in a network means that "shared understandings" inform corporate policies and practices. Applied to modern slavery, network involvement implies that firms can learn from their peers on how to address its causes and remedy its consequences. There is already evidence of this having happened in the retail sector, with major firms coalescing around ethical sourcing standards promulgated by the Apparel Industry Partnership and the Fair Labor Association (Park-Poaps and Rees, 2010). This leads to the following hypothesis.

H4b Network participation is positively associated with corporate compliance on modern slavery reporting.

\subsection{Context}

Organisational context is also relevant in explaining how firms respond to institutional pressures. Two context-related dimensions are examined in this study. The first is industry. International Labour Organization (ILO) estimates point to the prevalence of forced labour in industries like construction, manufacturing, agriculture, accommodation and retail/wholesale (ILO, 2017). The labour intensive and low-skilled profile of these industries explain why they are susceptible to human trafficking and labour exploitation (Crane, 2013; Crane et al., 2017). Moreover, suppliers for these industries are often located in developing economies where legal protections for workers are negligible and modern slavery risks are severe (Walkfree Foundation, 2018). By contrast, finance and professional services industries employee predominantly high-skilled workers and have domestically-centred supply chains. The salience of modern slavery is likely to be less for firms in these industries, which feeds through to their interest in reporting on it. This is essentially what Birkey et al. (2018) found on the relationship between supply chain risk exposure and modern slavery reporting. Elsewhere, industry type has emerged as a significant determinant of how firms report on social responsibility matters (Reverte, 2009; Gamerschlag et al., 2011; Perez-Batrez et al., 2012). This leads to the following hypothesis.

H5a Industry is deterministic of corporate compliance on modern slavery reporting. Specifically, firms in low-skilled, labour-intensive industries are more likely to report on modern slavery than firms in high-skilled, value-adding industries. 
The second context-related dimension is resource availability. Instituting strategies to combat modern slavery requires firms to commit organisational resources. This can be inferred from research showing that firms are continually having to enhance the management of their operations and supply chains in response to social and environment challenges. This enhancement takes in not only structural adjustments like individual and team sustainability roles, but also policy changes like the adoption of ethical supplier codes, practice improvements like third-party audits and the expansion of performance reporting to include grievance, remediation and occupational health (Winstanley et al., 2002; Preuss, 2009; Eccles et al., 2014). Firms with a surplus of funds are in a position to make the necessary resource investments for acting against modern slavery and subsequently reporting on these actions in the public domain (Perez-Batres et al., 2012). The opposite is the case for firms in a precarious financial position. For them, managing and reporting modern slavery risks is likely to be an expense they could do without. This leads to the following hypothesis.

H5b Profitability is positively associated with corporate compliance on modern slavery reporting.

\section{Research Design}

\subsection{Population sample}

The population sample used in this study is the Financial Times Stock Exchange (FTSE) 350 list. FTSE 350 comprises the largest 350 firms by market capitalisation listed on the London Stock Exchange. The FTSE 350 sample was selected for the following reasons. First, its constituent members satisfy the $£ 36$ million turnover threshold at which firms are legally obliged to publish a modern slavery statement. Second, there is precedent for using FTSE-listed firms to investigate environmental, social and governance (ESG) matters in SCM (Brammer and Pavelin, 2006; Preuss, 2009; Preuss and Brown, 2012). Third, the size and marketplace presence of FTSE 350 firms means that action or inaction by them in combating modern slavery has ramifications for their entire supply chain.

\subsection{Data sources}

The data used in this paper is taken entirely from secondary sources. Data for the predictor variables was extracted from annual company reports and external databases like FAME, BoardEx and Financial Times Online. Data for the outcome variable was generated from an analysis of modern slavery statements made by firms. We explain this process in section 3.4. Secondary data is growing in importance in SCM research (Ellram and Tate, 2016) and can be found across many sustainable SCM studies (Walker and Jones, 2012; Kauppi and Hannibal, 2017). Its attractions include relative ease of access, opportunities for research replication and reduced likelihood of researcher or respondent bias skewing the eventual findings (Trzesniewski et al., 2011). It has drawbacks, too, including unstructured or incomplete formats and the fact that researchers have no discretion over how the variables are designed or measured (Ellram and Tate, 2016). In this study, data for the predictor variables was collected for the financial year-end 2015 and data for the outcome variable was collected for the financial year-end 2016. The one-year time lag was designed to obviate any concern about reverse causation.

\subsection{Predictor variables}

Eight predictors and a control variable were used in the model. Summary information on the operationalisation, measurement and data source for each variable is contained in Table 1 . Unless otherwise stated, data was collected for the financial year-end 2015. Firm size was operationalised in terms of annual turnover. Non-executive representation was operationalised as the percentage of company board members classed as non-executive. Shareholder concentration was operationalised as the three highest individual shareholdings expressed as a combined percentage of ordinary share capital. Social responsibility commitment was operationalised by reference to firms being a signatory 
to the UN Global Compact, UN Responsible Investment Principles and Ethical Trade Initiative (ETI) Base Code. Each of these international accords commits signatories to socially responsible business practice. Both the UN Global Compact and ETI Base Code explicitly refer to the elimination of forced labour and child labour. The UN Responsible Investment Principles are aimed at promoting ethical investment. Signatories to each accord on or before 2015 were coded 1. Non-signatories were coded 0.

Network involvement was operationalised as participation in named ESG networks. Networks could be sector-specific (e.g. International Council on Mining and Metals), cross-sector (e.g. Business for Social Responsibility) or established to combat labour rights abuses in particular countries (e.g. Project Issara in the Thai prawn sector). Corporate sustainability reports and company literature was consulted to identify network involvement for each firm. The number of ESG networks identified for each firm was taken as our measure. Media exposure was operationalised as the total number of Financial Times newspaper articles that mentioned a firm in the context of modern slavery between 1996 and 2015. The Financial Times was used because of its preeminent status as the newspaper of record for business and economic affairs. Articles were identified by using keyword search term combinations of the company name and "modern slavery" or "child labour" or "forced labour" in the online archive of the Financial Times.

Standard Industrial Classification (SIC) codes were used to identify the corresponding industry for each firm. The fifteen industry classes relevant to our sample were mining and quarrying; manufacturing; utilities (electricity and water); construction; wholesale and retail; transportation and storage; accommodation and food; information and communication; finance and insurance; real estate; professional, scientific and technical; administrative; public administration and defence; human health; arts, entertainment and other services. Profitability was operationalised as return on total assets (ROTA). Headquarter location served as a control variable. It was treated dichotomously, split between UK-headquartered and non-UK headquartered firms. Given that the study investigates corporate compliance with a UK piece of legislation, it was felt that the primary jurisdictional base of the firm should be controlled for in the model.

\subsection{Outcome variable}

The outcome variable, corporate compliance, was operationalised as the extent to which firms adhered to the Transparency in Supply Chains provision of the UK Modern Slavery Act. In concrete terms, this meant assessing the content of modern slavery statements against seven areas the Act advises firms to report on. The seven areas are (1) supply chain information (2) policies for combating modern slavery (3) due diligence on modern slavery (4) risk assessment of modern slavery (5) risk management of modern slavery (6) performance measurement on modern slavery prevention and (7) training on modern slavery awareness. Firms with a statement that contained information on any one of the seven areas were scored 1 , firms with a statement that contained information on any two of the seven areas were scored 2 and so forth. Firms with no modern slavery statement were scored 0.

The integrity of the scoring process was ensured through the use of a coding protocol (see Table 2). The protocol listed indicators associated with each of the seven areas. For example, due diligence indicators included "questionnaires", "audit", "onsite assessment" and "vetting". Similarly, risk management indicators included "contractual clauses", "supplier attestations", "remediation", "termination" and "flow-down provisions". The identification of one or more indicators discussed in the context of modern slavery and supply chains meant that the firm was adjudged to have reported on the particular area. The indicators were arrived at by consulting relevant academic literature (Preuss, 2009; Preuss and Brown, 2012; New, 2015; Stevenson and Cole, 2018), ex-ante assumptions 
about what firms would report and by sampling 50 modern slavery statements prior to the scoring process commencing proper.

Two researchers worked together in assessing and scoring the statements. The use of the coding protocol supported consistency and transparency in the scoring process. Moreover, it provides guidance to other researchers should they wish to replicate some or all of this study. As an additional check on the robustness of the approach, the compliance score for each firm was correlated with statement length. Statement length was measured by the number of pages. The assumption was that firms with higher compliance scores will have provided more information in their statements, which should be reflected in statement length. The assumption proved correct. The degree of correlation between compliance scores and statement length was 0.689 , significant at $p<.001$.

\subsection{Compliance types}

Having completed the assessment and scoring process, firms were categorised according to Oliver's (1991) institutional response types of defiance, avoidance, compromise and acquiescence. Defiance is defined as non-conformity to institutional expectations on modern slavery reporting. Firms with no modern slavery statement were deemed to be defiant. Avoidance is defined as tokenistic conformity to institutional expectations on modern slavery reporting. Firms with a modern slavery statement that contained information on one to three of the recommended areas were classed as avoidance cases. Compromise denotes partial conformity to institutional expectations on modern slavery reporting. Firms with a modern slavery statement that contained information on four to six of the recommended areas were said to be compromising. Acquiescence is defined as full conformity to institutional expectations on modern slavery reporting. Acquiescent firms had a modern slavery statement that contained information on all seven recommended areas.

A fifth type of response - manipulation - that comprises Oliver's (1991) typology is not included in this study. The reason being that manipulation by firms in the context of modern slavery reporting would have occurred prior to the adoption of the Transparency in Supply Chains provision by the UK government. As Oliver (1991, p. 157) explains, manipulation is when firms attempt to "change or exert power over the content of the [institutional] expectations themselves". For instance, firms may have lobbied the UK government to ensure that their legal obligations did not extend beyond reporting their anti-slavery strategies. To gather evidence of manipulation we would need to investigate the industry consultation process that took place in the lead-up to the enactment of the UK Modern Slavery Act. However, as the scope of this study is limited to modern slavery statements it is all but impossible to detect evidence of manipulation. As a result, we exclude manipulation as a response type. We acknowledge its omission and highlight the need for future research to explore if industry actors manipulated institutional expectations on combating modern slavery.

\subsection{Data screening and preliminary analysis}

The dataset was screened for completeness prior to running the statistical tests. Six cases were removed because of missing data. An additional nine cases were removed because of duplication of modern slavery statements. Duplication in this instance refers to two or more entities listed on the FTSE 350 and covered by the same group statement (e.g. John Laing Group Plc and John Laing Infrastructure Fund Ltd). The final number of usable cases was 335. Descriptive statistics and correlations for the predictor and outcome variables are contained in Table 3. The highest Pearson Correlation Co-efficient value was 0.59 . This indicates that multi-collinearity is not present. Tolerance and Variance Inflation Factor (VIF) diagnostic tests confirmed this observation. Tolerance values did not go below 0.43 and VIFs did not go above 2.28. 


\section{Findings}

Ordered logistic regression (probit) was used to test the effect of the predictor variables on compliance with modern slavery reporting. Ordered logistic regression is designed for cases where the dependent variable contains a number of ranked categories. The corporate compliance variable used in this study is an example of a dependent variable with ranked categories. It goes from defiance (0) to avoidance (1) to compromise (2) to acquiescence (3). Had corporate compliance been measured at interval level we would expect to use standard linear regression. As with regression models generally, the purpose of ordered logistic regression is to test how accurately the dependent variable can be predicted by independent variables. Ordered logistic regression rests on the assumption of proportional odds. This means that a predictor variable is assumed to have an identical effect at each level of the dependent variable. For a detailed treatment of ordered logistic regression refer to O'Connell (2006).

The ordered logistic regression in this study was run using IBM SPSS Statistics 23 programme. The first step in the process was to assess how well the model fitted the data. Model Fitting Information confirmed that the final predictive model was a significant improvement on the intercept-only model $(X=167.96, d f=24, p<.001)$. The model was found to explain over $42 \%$ of the variance in compliance with modern slavery reporting (Nagelkerke $=0.429$ ). Maximum likelihood methods were used to estimate the parameters of the model. Parameter estimates indicate which predictor variables are statistically significant in explaining compliance. Cumulative odds ratios for the predictor variables were also calculated using SPSS Output Management System (OMS). Odds ratios give the odds that a predictor variable has a higher or lower value on the dependent variable. Parameter estimates and cumulative odds are reproduced in Table 4.

We start our presentation of findings with variables that did have a statistically significant effect on compliance. Firm size is significant at $\mathrm{p}<.10$. This gives qualified support to $\mathrm{H} 1$, which argues that the institutional visibility of larger firms puts them under pressure to take a proactive stance against modern slavery. Also as hypothesised, prior social responsibility commitment increases the likelihood that firms respond positively $(p<.01)$. Specifically, signatories to the UN Global Compact are almost twice as likely to comply with modern slavery reporting as non-signatories. Significant associations were not observed for either the UN Responsible Investment Principles or ETI Base Code. For the former, this can be explained by most of its signatories operating in the finance and insurance sector which, as will be described below, exhibited low levels of reporting compliance. Network involvement is the strongest predictor of compliance $(p<.01)$. The likelihood of network participants conforming to modern slavery reporting requirements is 2.18 times that of non-participants ( $95 \% \mathrm{Cl}, 1.60$ to 2.99 ). As $\mathrm{H} 4 \mathrm{~b}$ contends, network involvement acts as a source of mimetic or peer pressure on firms to enact institutionally-sanctioned business practices.

Industry is also significant in explaining firms' stance on modern slavery reporting, which $\mathrm{H} 5 \mathrm{a}$ predicted. Compared with finance and insurance, which serves as the reference category, manufacturing, construction, wholesale and retail, accommodation and food, transport and other industries besides are more likely to give effect to the reporting requirements of the UK Modern Slavery Act. In fact, with the exception of real estate, public administration and mining all other industries have a higher probability of compliant behaviour than finance and insurance. This extends up to a three-time probability in the case of manufacturing and accommodation industries. These industry effects indicate that the salience of modern slavery to firms depends on their business model, employee profile and supply chain configuration. Headquarter location also matters. UKheadquartered firms are almost 1.5 times as likely to demonstrate compliance as non-UK 
headquartered firms. Evidently, proximity to the institutional rule setter, in this case the UK government, engenders compliant behaviour.

Other results go against hypothesised predictions. Non-executive representation on company boards is significantly but negatively related to compliance. The expectation was that a positive relationship would exist. Subsequent investigation of this surprising finding traced its cause to the many instances of investment firms with exclusively non-executive boards not publishing a modern slavery statement. $\mathrm{H} 2 \mathrm{~b}$ predicted that shareholder concentration would be inversely related to compliance. While an inverse relationship is observed it is not statistically significant. Media exposure was hypothesised to induce compliance on the basis that it represents a normative pressure on firms. No support was forthcoming, leading to rejection of $\mathrm{H} 4 \mathrm{a}$. Possibly, the operationalisation of media exposure relied on in this study was too narrow and needed to include sources other than newspapers. Finally, profitability is not associated with compliance and so $\mathrm{H} 5 \mathrm{~b}$ is rejected. This runs contrary to prevailing thinking on the relationship between financial resources and responsible business practice. We discuss it and the other negative findings in section 5.

\subsection{Binary logistic regression}

A second round of statistical tests was undertaken to examine the effect of the predictor variables on the likelihood of a firm either acquiescing, compromising, avoiding or defying modern slavery reporting requirements (see Table 5). This involved treating each of the four compliance types as dichotomous variables and then regressing them on the same set of predictor variables using binary logit models. As with the ordered logistic regression, maximum likelihood procedures were used to estimate the parameters of each logit model. Each of the four models was significant at $p<.01$ or better. The variance explained ranges from $15 \%$ in the case of compromise to $66 \%$ in the case of defiance. The lowest prediction accuracy rate across the four models is $66.9 \%$ and the highest is $91.6 \%$. The results from the logit models offer nuance by isolating the statistically significant factors associated with each of the four discrete response types. The findings to emerge from this exercise are set out below.

Acquiescence with modern slavery reporting requirements is primarily associated with firms that are signatories to UN Global Compact and involved in ESG networks. This implies that an acquiescent stance has its antecedents in, first, how congruent the UK Modern Slavery Act is with pre-existing corporate objectives and values and, second, the mimetic control mechanisms that the firm experiences. These represent the content and control dimensions of our model, respectively. By contrast, the compromise stance is linked to non-participation in networks and the type of industry. In respect of the latter, firms in industries like accommodation/food, construction, manufacturing, professional/scientific, wholesale/retail and transport are more likely to assume a compromise stance.

The only statistically significant characteristic of avoidance category firms is that they have low levels of non-executive board representation. Having fewer non-executives deprives firms of external and/or independent advice on managing their social responsibilities. The reason the original hypothesis was not supported becomes apparent when we isolate the characteristics of firms in the defiance category. These firms have high levels of non-executive representation on their company boards. When we investigated the matter further we found that $70 \%$ of defiant firms operated in the finance and insurance sector. It is common for investment firms to operate with small, entirely non-executive boards. This explains the anomalous result. Finally, defiant firms are, on average, smaller in size. As hypothesised, smaller size means reduced institutional visibility; and reduced institutional visibility means less onus to be institutionally compliant or more licence to be defiant.

\subsection{Findings summary}


The analyses presented above lead to two main conclusions. First, corporate responses to institutional pressures for modern slavery reporting are not uniform. They sit on a continuum that stretches from negative (defiance) to positive (acquiescence). Second, several organisational and environmental factors influence the position that firms occupy on this continuum. Mainly, these relate to fit or alignment between combating modern slavery and a firm's existing social responsibility orientation, the mimetic controls a firm is exposed to, the industrial context in which it operates and its size and headquarter location. There are also some factors that are specific to individual response types such as non-executive representation in the case of defiance and prior social responsibility commitment in the case of acquiescence. Taken together, the findings provide reasonable support to Oliver's (1991) thesis that how firms respond to institutional pressures is contingent on cause, constituents, content, control and context factors.

\section{Discussion}

Modern slavery is beginning to insert itself into SCM research, evidenced by recent assessments of the quantity and quality of information that firms are disclosing in their modern slavery statements (Stevenson and Cole, 2018). The purpose here has been to extend this nascent line of inquiry by testing the determinants of corporate compliance with modern slavery reporting. It represents among the first studies of its kind, with only Birkey et al. (2018) having previously investigated why US retailers adopt certain stances towards the California Transparency in Supply Chains Act. The findings of our study reveal that FTSE-listed firms have not responded uniformly to institutional expectations on modern slavery reporting. Even more importantly, our findings go some way towards explaining why this is the case. We discuss our findings below using Oliver's (1991) institutional theory framework for predicting corporate responses to institutional pressures.

\subsection{Theoretical confirmation}

Several of Oliver's (1991) theoretical assumptions about what promotes institutional compliance receive empirical support in our study. Among these is compatibility between organisational values and the content of institutional pressures. FTSE firms who have made a commitment to uphold human rights by joining the UN Global Compact are more compliant with modern slavery reporting. For such firms we can deduce that there is a compatibility, or even complementarity, between their espoused stance on socially responsible SCM and the ethical values that the UK Modern Slavery Act promulgates. Compliance is made easier as a result. Another theoretical assumption is that mimetic control mechanisms, which are proxied in this study by network involvement, pushes firms towards institutional compliance. Our finding that FTSE firms involved in ESG networks are more compliant is consistent with this assumption. Essentially, networks facilitate the diffusion of best practices and cause firms to coalesce around a behavioural standard (Campbell, 2007; Tate et al., 2011). Some FTSE corporations allude to this point in their modern slavery statements. Tesco Plc, for instance, claims that participation in the UK Stronger Together initiative "offers a support network where challenges and good practice can be shared among peers and experts" (Tesco, 2016).

Context is central to understanding how firms react to institutional pressures (Oliver, 1991). We find strong evidence of its role here. Specifically, context in the form of industry classification influences if and to what extent firms report on modern slavery. Even though firms across all industries are obliged to report, their fulfilment of this requirement varies substantially. One reason for this is the level of modern slavery risk that industries face (ILO, 2017; Walkfree Foundation, 2018). Industries with high risk exposure will devote greater resources to address modern slavery compared to industries with lower risk exposure. This explains why manufacturing firms are over-represented in the acquiescence category and why finance and insurance firms are over-represented in the defiance category. The final theoretical assumption confirmed relates to the connotations of the UK Modern Slavery Act. Previous 
research indicates that where institutional pressures have moral connotations, which is the case here, larger firms are expected by institutional stakeholders to demonstrate compliance and lead by example (Gamerschlag et al., 2011; Hoejmose et al., 2014a). Our finding that larger firms produce better modern slavery reports supports this reasoning.

Other theoretical assumptions about what promotes institutional compliance were not supported. Normative pressure stemming from media exposure did not affect corporate compliance with modern slavery reporting, which is contrary to what has emerged elsewhere on the adoption of sustainability practices in SCM (Park-Poaps and Rees, 2010; Sayed et al., 2017). It may be because we confined our operationalisation of media exposure to newspaper coverage of firms. A more expansive operationalisation that takes in coverage by other stakeholders - NGO press releases, for example might better capture its effect. Profitability also had no effect on compliance. This is noteworthy as financial strength has been shown to be an antecedent of CSR activity and disclosure across a number of studies (Haniffa and Cooke, 2005; Chih et al., 2010; Gamerschlag et al., 2011; Perez-Batres et al. 2012), although negative results can also be found (Barako et al., 2006; Reverte, 2009). Conceivably, it is less financial resources than intangible resources like organisational culture that spur firms towards developing and subsequently reporting on modern slavery strategies. Further research is advised to probe the role of both tangible and intangible organisational resources on responsible SCM practices.

Institutional constituents, as Oliver (1991) noted, press firms into particular ways of acting. Assumptions in this study about the role of constituents in driving compliance with modern slavery reporting go unsubstantiated. Non-executive presence on company boards yielded a negative effect and shareholder concentration yielded no effect. This suggests that we should look beyond shareholders and directors to other stakeholder groups like suppliers, customers and investors when investigating the drivers of compliance with modern slavery reporting. We return to this point in section 6.2.

\subsection{Contributions}

This study makes empirical and theoretical contributions to the SCM field. Empirically, it presents important new findings on the factors that explain corporate responses to institutional demands for transparency over modern slavery risks in supply chains. Some of these findings confirm our a priori assumptions. Other findings confound them. Taken together, the study and its findings build on current SCM lines of inquiry into modern slavery specifically (Gold et al., 2015; New, 2015; Birkey et al., 2018; Stevenson and Cole, 2018) and socially responsible sourcing generally (Zorzini et al., 2015; Nakamba et al., 2017). Theoretically, our operationalisation and testing of Oliver's (1991) framework on corporate responses to institutional pressures is novel for sustainable SCM research. While SCM scholars have used institutional pressures to rationalise why firms attempt to make their supply chains "green" or ethical (Tate et al., 2011; Hoejmose et al., 2014b; Sancha et al., 2015; Kauppi and Hannibal, 2017; Sayed et al., 2017), we go down a different path by testing the effect that various organisationalenvironmental factors have on corporate responses to these pressures. In doing so we demonstrate how institutional theory can be used in new ways for researching sustainable SCM phenomena.

\section{Conclusion}

This study has sought to advance knowledge on modern slavery in a SCM context by examining the determinants of corporate compliance with the Transparency in Supply Chains provision of the UK Modern Slavery Act. Its findings point to the contingent nature of compliance with modern slavery reporting, showing that factors as diverse as cause, context, constituents, content and control have a part to play in how firms respond. This is a novel insight for the field, an insight that is grounded in 
institutional theory. The study goes some way towards redressing the paucity of evidence on the implications of modern slavery risks for supply chains (Gold et al., 2015; New, 2015) and builds on existing attempts at conceptualising and theorising modern slavery as the phenomenon of interest (Crane, 2013; Crane et al., 2017). Its contribution is timely given the growing prevalence of modern slavery in developed and developing economies and a corresponding insistence from political, religious, business and labour leaders that every effort must be made by firms to counteract it.

\subsection{Managerial and policy implications}

The paper has a number of managerial and policy implications. Senior managers committed to socially responsible supply chains should explore the option of joining a network like AIM-Progress or signing up to an international accord like the UN Global Compact. Either of these actions will generate positive momentum behind organisational efforts to deal with modern slavery risks. At public policy level, the Office of the Independent Anti-Slavery Commissioner should take note that some of the largest publicly-listed firms in the UK have yet to produce a modern slavery statement. Over $70 \%$ of these non-compliant firms are in finance and insurance. Ostensibly, finance and insurance firms are unaffected by modern slavery risks. However, as the Financial Action Task Force (2018) makes clear, the risk of the proceeds of modern slavery crime entering the financial system is high. Hence there is a case for stronger government intervention with this sector. Ultimately this may mean bringing civil proceedings in the High Court against firms for persistent non-compliance.

Modern slavery reporting is a step in the right direction for responsible SCM. The challenge now for policy makers is how to maintain progress. One option is to make firms include modern slavery metrics in the governance section of their annual company report. Relevant here could be number of supplier audits carried out, number of complaints received through whistleblowing channels, number of supplier contracts terminated etc. This would have the advantage of standardising modern slavery reporting, ensuring modern slavery risk metrics reach a wider audience of stakeholders and making it easier for all stakeholders to observe year-on-year improvements by firms in managing modern slavery risks. A final policy implication is to do with the effects of modern slavery strategies on smaller actors in the supply chain. Certain FTSE 350 firms require their tier one suppliers to pay UK Living Wage rates, adopt modern slavery policies and give guarantees about tier two suppliers' ethical credentials. This could prove challenging for small firms in terms of cost competitiveness and administrative workload. For this reason policy makers need to be alive to the unintended consequences of introducing the Transparency in Supply Chains provision and monitor its impact.

\subsection{Limitations and future research}

There are limitations to this study. First, it confines its analysis to the largest 350 publicly-listed firms in the UK. The determinants of reporting compliance outside of the FTSE 350 cohort go untested. Future research may want to consider sampling some other of the approximately seven thousand large firms in the UK, including universities, which fall under the remit of the UK Modern Slavery Act. It would also be instructive to check the external validity of the findings by replicating the study in Australia. Its Modern Slavery Act, which includes legal reporting obligations for corporations, came into force on January $1^{\text {st }} 2019$. Second, the paper tests institutional determinants of compliance with modern slavery reporting but not economic-efficiency determinants. The latter also shape how firms respond to demands made of them by regulators and professional bodies (Meyer and Rowan, 1977). To account for economy-efficiency determinants, it is recommended that future studies survey firms on the financial costs and benefits of creating an organisational architecture for combating modern slavery. These cost and benefit factors would then be hypothesised to impede and promote compliance, respectively. 
Third, the specification and operationalisation of variables used in this study can be improved on. We have already conceded that operationalising media exposure exclusively in terms of newspaper articles overlooks normative pressure emanating from NGO activism. Substituting newspaper articles with a more expansive measure of media coverage such as Thomson Reuters ESG controversy scores is one way forward. There is also scope to introduce alternative predictor variables into the model. For instance, public sector buying organisations are a constituent group that could influence private sector compliance with modern slavery reporting. The working hypothesis is that the higher the proportion of revenue a firm derives from public sector customers, the more pressure it is under to exhibit compliance. Finally, it should be noted that the study uses the inaugural modern slavery statements published for the financial year-ending 2016. It is probable that compliance will improve in the second and subsequent years of reporting as firms become attuned to institutional standards. This is a conclusion Stevenson and Cole (2018) also reached. Therefore, re-testing the predictors of compliance with modern slavery reporting over the coming years is recommended.

\section{References}

Antislavery International. (Undated), "What is modern slavery?", available at: https://www.antislavery.org/slavery-today/modern-slavery/ (accessed 15 April 2018).

Barako, D.G., Hancock, P. and Izan, H.Y. (2006), "Factors influencing voluntary corporate disclosure by Kenyan companies", Corporate Governance: An International Review, Vol. 14 No. 2, pp. 107-125.

Barclays. (2016), Barclays Modern Slavery Statement 2016, Barclays, London.

BBC.co.uk. (2016), "Bed firm boss convicted over slave workforce", available at: https://www.bbc.co.uk/news/uk-england-leeds-35363259 (accessed 20 Jan 2017).

Birkey, R.N., Guidry, R.P., Islam, M.A. and Patten, D.M. (2018), “Mandated social disclosure: an analysis of the response to the California Transparency in Supply Chains Act of 2010", Journal of Business Ethics, Vol. 152 No.3, pp.827-841.

Brammer, S. and Pavelin, S. (2006), "Voluntary environmental disclosures by large UK companies", Journal of Business Finance \& Accounting, Vol. 33 No. 7/8, pp. 1168-1188.

Burgess, K. (2018), "Churchgoers taught to spot modern slaves", The Times, 31 March, 2018.

Campbell, J.L. (2007), "Why would corporations behave in socially responsible ways? An institutional theory of corporate social responsibility", Academy of Management Review, Vol. 32 No. 3, pp.946967.

Carter, C.R. and Liane Easton, P. (2011), "Sustainable supply chain management: evolution and future directions", International Journal of Physical Distribution and Logistics Management, Vol. 41 No 1, pp. 46-62.

Crane, A. (2013), "Modern slavery as a management practice: Exploring the conditions and capabilities for human exploitation", Academy of Management Review, Vol. 38 No. 1, pp. 49-69.

Crane, A., LeBaron, G., Allain, J. and Behbahani, L. (2017), "Governance gaps in eradicating forced labor: from global to domestic supply chains", Regulation \& Governance, https://doi.org/10.1111/rego.12162. 
Deegan, C. and Islam, M.A. (2014), "An exploration of NGO and media efforts to influence workplace practices and associated accountability within global supply chains", The British Accounting Review, Vol. 46 No. 4, pp.397-415.

DiMaggio, P.J. and Powell, W.W. (1983), "The iron cage revisited: Collective rationality and institutional isomorphism in organizational fields", American Sociological Review, Vol. 48 No. 2, pp. 147-160.

Dowling, J. and Pfeffer, J. (1975), "Organizational legitimacy: social values and organizational behaviour", Pacific Sociological Review, Vol. 18 No. 1, pp. 122-136.

Eccles, R.G., loannou, I. and Serafeim, G. (2014), "The impact of corporate sustainability on organizational processes and performance", Management Science, Vol. 60 No. 11, pp. 2835-2857.

Eisenhardt, K.M. (1989), "Agency theory: an assessment and review", Academy of Management Review, Vol. 14 No. 1, pp. 57-74.

Ellram, L.M. and Tate, W.L. (2016), "The use of secondary data in purchasing and supply management (P/SM) research", Journal of Purchasing and Supply Management, Vol. 22 No.4, pp. 250-254.

Financial Action Task Force and Asia-Pacific Group on Money Laundering. (2018), Financial Flows from Human Trafficking. FATF, Paris, available at: www.fatf-

gafi.org/publications/methodandtrends/documents/human-trafficking.html (accessed 25 August 2018).

Gamerschlag, R., Möller, K. and Verbeeten, F. (2011), "Determinants of voluntary CSR disclosure: empirical evidence from Germany", Review of Managerial Science, Vol. 5 No. 2-3, pp.233-262.

Gold, S., Trautrims, A. and Trodd, Z. (2015), "Modern slavery challenges to supply chain management", Supply Chain Management: An International Journal, Vol. 20 No. 5, pp. 485-494.

Haniffa, R.M. and Cooke, T.E., (2005), "The impact of culture and governance on corporate social reporting", Journal of Accounting and Public Policy, Vol. 24 No. 5, pp. 391-430.

HM Government. (2015), Transparency in Supply Chains: A Practical Guide, HM Government, Westminster.

HM Government. (2017), 2017 UK Annual Report on Modern Slavery, HM Government, Westminster.

Hoejmose, S.U., Roehrich, J.K. and Grosvold, J, (2014a), "Is doing more doing better? The relationship between responsible supply chain management and corporate reputation", Industrial Marketing Management, Vol. 43 No. 1, pp.77-90.

Hoejmose, S.U., Grosvold, J. and Millington, A. (2014b), "The effect of institutional pressure on cooperative and coercive 'green' supply chain practices", Journal of Purchasing and Supply Management, Vol. 20 No. 4, pp. 215-224.

International Labour Organization (ILO). (2012), ILO Global Estimate of Forced Labour, International Labour Organization, Geneva.

International Labour Organization (ILO). (2017), Global Estimates of Modern Slavery: Forced Labour and Forced Marriage, International Labour Organization, Geneva.

Kauppi, K. and Hannibal, C. (2017), "Institutional pressures and sustainability assessment in supply chains", Supply Chain Management: An International Journal, Vol. 22 No. 5, pp. 458-472. 
Meyer, J.W. and Rowan, B. (1977), "Institutionalized organizations: formal structure as myth and ceremony", American Journal of Sociology, Vol. 83 No. 2, pp. 340-363.

Nakamba, C.C., Chan, P.W. and Sharmina, M. (2017), "How does social sustainability feature in studies of supply chain management? A review and research agenda", Supply Chain Management: An International Journal, Vol. 22 No. 6, pp. 522-541.

New, S.J. (2015), "Modern slavery and the supply chain: the limits of corporate social responsibility? Supply Chain Management: An International Journal, Vol. 20 No. 6, pp. 697-707.

O'Connell, A.A. (2006), Logistic Regression Models for Ordinal Response Variables (No. 146), Sage, California.

Office of the Independent Antislavery Commissioner. (2018a), "Joint investor action on corporate modern slavery statements", available at: https://www.antislaverycommissioner.co.uk/newsinsights/ioint-investor-action-on-corporate-modern-slavery-statements/(accessed 30 May 2018).

Office of the High Commissioner for Human Rights. (Undated), United Nations Slavery Convention, available at: https://www.ohchr.org/en/professionalinterest/pages/slaveryconvention.aspx (accessed 10 April 2018).

Oliver, C. (1991), "Strategic responses to institutional processes", Academy of Management Review, Vol. 16 No. 1, pp. 145-179.

Park-Poaps, H. and Rees, K. (2010), "Stakeholder forces of socially responsible supply chain management orientation", Journal of Business Ethics, Vol. 92 No. 2, pp. 305-322.

Perez-Batres, L.A., Doh, J.P., Miller, V.V. and Pisani, M.J. (2012), "Stakeholder pressures as determinants of CSR strategic choice: why do firms choose symbolic versus substantive self-regulatory codes of conduct?" Journal of Business Ethics, Vol. 110 No. 2, pp.157-172.

Preuss, L. and Brown, D. (2012), "Business policies on human rights: an analysis of their content and prevalence among FTSE 100 firms”, Journal of Business Ethics, Vol. 109 No. 3, pp. 289-299.

Preuss, L. (2009), "Ethical sourcing codes of large UK-based corporations: prevalence, content, limitations", Journal of Business Ethics, Vol. 88 No. 4, pp. 735-747.

Reverte, C. (2009), "Determinants of corporate social responsibility disclosure ratings by Spanish listed firms", Journal of Business Ethics, Vol. 88 No. 2, pp.351-366.

Roberts, J., McNulty, T. and Stiles, P. (2005), "Beyond agency conceptions of the work of the nonexecutive director: creating accountability in the boardroom", British Journal of Management, Vol. 16, Supplement1, pp.S5-S26.

Sancha, C., Longoni, A. and Giménez, C. (2015), "Sustainable supplier development practices: drivers and enablers in a global context", Journal of Purchasing and Supply Management, Vol. 21 No. 2, pp. 95-102.

Sayed, M., Hendry, L.C. and Zorzini Bell, M. (2017), "Institutional complexity and sustainable supply chain management practices", Supply Chain Management: An International Journal, Vol. 22 No. 6, pp. 542-563.

Scott, W.R. (2008), Institutions and Organizations: Ideas and Interests, Sage, California. 
Sky News. (2018), "Inside the Congo mines that exploit children", available at: https://news.sky.com/video/inside-the-congo-mines-that-exploit-children-10784310 (accessed on 21 March 2018).

Stevenson, M. and Cole, R. (2018), "Modern slavery in supply chains: a secondary data analysis of detection, remediation and disclosure", Supply Chain Management: An International Journal, Vol. 12 No. 3, pp. 81-99.

Tate, W.L., Dooley, K.J. and Ellram, L.M. (2011), "Transaction cost and institutional drivers of supplier adoption of environmental practices", Journal of Business Logistics, Vol. 32 No. 1, pp. 6-16.

Tesco. (2016), Tesco Modern Slavery Statement 2016, Tesco, UK.

Touboulic, A. and Walker, H. (2015), "Theories in sustainable supply chain management: a structured literature review", International Journal of Physical Distribution and Logistics Management, Vol. 45 No. $1 / 2$, pp. 16-42.

Trzesniewski, K.H., Donnellan, M. and Lucas, R.E. (2011), Secondary Data Analysis: An Introduction for Psychologists. American Psychological Association, New York.

Walker, H. and Jones, N. (2012), "Sustainable supply chain management across the UK private sector", Supply Chain Management: An International Journal, Vol. 17 No. 1, pp.15-28.

WalkFree Foundation. (2018), The Global Slavery Index 2018, Walkfree Foundation, Western Australia.

Winstanley, D., Clark, J. and Leeson, H. (2002), "Approaches to child labour in the supply chain", Business Ethics: A European Review, Vol. 11 No. 3, pp.210-223.

Zorzini, M., Hendry, L.C., Huq, F.A. and Stevenson, M. (2015), "Socially responsible sourcing: reviewing the literature and its use of theory", International Journal of Operations \& Production Management, Vol. 35 No. 1, pp.60-109. 
